УДК 738.147

О.В. ПАХОЛЮК

Луиький наиіональний технічний університет

І.С. ГАЛИК, Б.Д. СЕМАК

Львівський торговельно-економічний університет

\title{
КЛЮЧОВІ КОМПЕТЕНТНОСТІ КЕРІВНИКА СУЧАСНОГО СУПЕРМАРКЕТУ НЕПРОДТОВАРІВ
}

\author{
Е.В. ПАХОЛЮК
}

Луиякий национальный технический університет

И.С. ГАЛИК, Б.Д. СЕМАК

Львовский торгово-экономический университет

\author{
КЛЮЧЕВЫЕ КОМПЕТЕНТНОСТИ РУКОВОДИТЕЛЯ \\ СОВРЕМЕННОГО СУПЕРМАРКЕТА НЕПРОДТОВАРОВ
}

\begin{abstract}
E. PAKHOLIUK
Lutsk national technical university

I. GALIK, B. SEMAK

Lviv trade and economic university

\section{KEY COMPATIBILITIES OF THE CHAIRMAN OF THE MODERN SUPERMARKET OF NON-FOOD PRODUKTS}

\section{https://doi.org/10.36910/6775-2310-5283-2019-12-32}

Мета. На основі аналізу літературних джерел і узагальнення результатів власних досліджень сформулювати та обтрунтувати перелік загальних $i$ професійних управлінських компетентностей керівників супермаркетів на прикладі компанії гуртовороздрібної торгівлі будівельними та господарськими товарами - «Епіцентр К».

Методика. При проведенні досліджень використовували передбачені діючими державними стандартами методи. Виконали огляд джерел товарознавчої та медичної літератури, здійснили моніторинг і систематизацію отриманих даних.

Результати. На основі узагальнення літературних джерел $і$ результатів власних досліджень сформульовано та обтрунтувано перелік наступних трьох груп управлінських компетентностей керівників супермаркетів на прикладі компанії гуртово-роздрібної торгівлі будівельними та господарськими товарами - «Епіщентр К»: загально торгівельні, товарознавчо-комериійні $i$ «товарні»

Наукова новизна. Вивчено можливості використання компетентнісного підходу $у$ вузах сфери торгівлі для підготовки управлінців-менеджерів для керівництва супермаркетами різноманітних торговельних компаній.

Практична значимість. Виявлена потреба посилення професійної управлінської підготовки випускників магістратури, оскільки саме в процесі навчання в магістратурі, випускники факультету товарознавства управління та сфери обслуговування повинні 
набувати необхідні їм у майбутній професійній діяльності управлінські професійні компетентності керівників торговельних підприємств різного типу.

Ключові слова: компетентність, компетентнісний підхід, керівник, управлінецьменеджер, торговельна мережа, супермаркет, професійні компетентності, непродовольчі товари.

Постановка проблеми у загальному вигляді та її зв'язок із важливими науковими чи практичними завданнями. Як відомо, в останні роки у сфері торгівлі в Україні, як і в багатьох європейських країнах, чітко намітилась тенденція розвитку крупноформатної мережі різноманітних магазинів (торгових центрів, універмагів, універсамів, супермаркетів та інших структур), які спеціалізуються не тільки на гуртово-роздрібній торгівлі різноманітними групами і видами непродовольчих товарів, але й наданню населенню різноманітних послуг. Прикладом може служити відома вітчизняна торгівельна компанія «Епіцентр К», яка спеціалізується на продажі будівельних матеріалів, господарських товарів, авто товарів, товарів для саду та городу, дитячих товарів, товарів спортивного призначення та інших. Це найбільша вітчизняна торгівельна компанія, що налічує 45 супермаркетів, загальною площею близько 1 млн.м² [1].

Окрім «Епіцентру К» в Україні успішно процвітають в останні роки і інші відомі компанії (наприклад, Метро, Фокстрот, Ельдорадо та інші), які спеціалізуються на оптово-роздрібній торгівлі різноманітних непродовольчих товарів вітчизняного та зарубіжного виробництва. Кожна 3 названих компаній володіє своєю мережею крупно форматних магазинів. Тому, виникає нагальна потреба підготовки керівників названих магазинів та сформулювати i обгрунтувати для них перелік ключових загальних $\mathrm{i}$ професійних компетентностей.

Необхідність вирішення цього завдання обумовлена ще й тим, що перелік необхідних компетентностей для керівників торговельних крупноформатних підприємств (універмагів, універсамів, супермаркетів, гіпермаркетів та інших) до цього часу, ще не описані та не обгрунтовані в існуючих підручниках із товарознавства непродовольчих товарів i iнших нормативно-правових документах.

Як свідчить аналіз літературних джерел [2-5], а також результати наших досліджень [6-9], компетентнісний підхід в останні роки почав використовуватись і для вдосконалення та переорієнтації системи підготовки фахівців товарознавчо-комерційного профілю для потреб сфери вітчизняної торгівлі. Разом з тим, в літературних джерелах є ще обмежена інформація, яка 
стосується особливостей формування в процесі навчання у вузах загальних і професійних компетентностей тим випускникам, практична діяльність яких у сфері торгівлі буде пов'язана 3 потребами набуття управлінськоменеджерських професійних компетентностей. Особливо це стосується необхідності набуття в процесі навчання випускниками товарознавчих факультетів тих професійних управлінських компетентностей, які пов’язані із знаннями специфіки асортименту, властивостей, методів оцінки якості та безпечності конкретних видів і груп непродовольчих товарів. Це так звані «товарні» компетентності, які у сфері торгівлі $\epsilon$ найменш вивченими та обгрунтованими [6-8].

Все це вимагає проведення поглиблених товарознавчих досліджень, націлених на конкретизацію та обгрунтування переліку загальних i професійних компетентностей управлінців-менеджерів різних типів торговельних підприємств, які відрізняються асортиментною структурою товарів, торговельними площами, обсягом товарообігу та іншими ознаками.

Аналіз останніх досліджень, у яких започатковано вирішення проблеми. В даній роботі ми обмежимось тільки аналізом тих літературних джерел, які безпосередньо пов'язані із формуванням конкретних загальних i професійних компетентностей управлінців-менеджерів (керівників різних підприємств).

Автором роботи [2] дано обгрунтування доцільності подальшого вдосконалення системи вітчизняної товарознавчої освіти, від якої залежить не тільки термін і ефективність входження України в ринкову економіку, але й успішне оволодіння досвідом міжнародних торговельно-економічних відносин на рівні підприємств і організацій. Відзначається, що за останні роки в Україні торгівля стала одним із найважливіших секторів економіки. Тому попит на фахівців торгівлі на ринку праці завжди був стабільним.

У роботі [2], також сформульовані та обгрунтовані вимоги до системи професійної освіти фахівців товарознавчого профілю. Розглянуто чинники, які впливають на формування якості професійної підготовки у вузах управлінцівменеджерів товарознавчо-комерційного профілю. Підкреслюється, що поняття: управління, керівництво, менеджмент утворюють синонімічний ряд i практично мало відрізняються між собою.

Відзначається, що провідною ознакою управлінської компетентності із врахуванням думок багатьох авторів, $\epsilon$ iï невід'ємність від загальної професійної компетентності фахівців даного профілю. При цьому, підкреслюється, що кінцевою метою формування управлінської 
компетентності має бути конкурентоспроможний фахівець товарознавчого профілю, здатний успішно вирішувати поставлені перед ним управлінські завдання.

Відзначається, що суттєвим для процесу підготовки управлінцяменеджера товарознавчого профілю у вузах $є$ всестороннє вивчення принципів формування та класифікації його управлінських функцій. Підкреслюється, що в структурі управлінської компетентності фахівців товарознавчого профілю доцільно виокреслити такі чотири компоненти: освітній, когнітивний, особистісний, поведінковий.

Автором роботи [3] подано теоретичне обгрунтування феномену лідерства як функції професійної компетентності особистості. Розкрито сутність названого феномена та дана характеристика відмінних ознак лідера та керівника колективу. Дано аналіз різних теорій та концепцій формування лідерства. Підкреслюється, що нині існує три основні напрями концепцій лідерства:

- концепції, в яких надається перевага фактору рис особистості;

- концепції, в яких домінують фактори ситуацій;

- концепції, в яких поєднуються особистісні та ситуаційні фактори.

Відзначається, що лідерство $\epsilon$ однією із найважливіших функцій психологічної компетентності особистості. Це зумовлює сутнісну характеристику основних рис лідера: він повинен мати послідовників. Лідерство завжди базується на авторитеті лідера. Названі такі основні відмінні ознаки лідера та керівника:

- керівник призначається офіційно, а лідер висувається неофіційно;

- $\quad$ права та повноваження керівнику надаються законом, а лідер не має потрібних прав;

- керівник несе персональну відповідальність за діяльність колективу, який він очолює, а лідер не несе їі.

При цьому відзначається, що бажано, щоб керівник колективу одночасно був його лідером, оскільки лідерство сприяє підвищенню ефективності реалізації керівником його управлінських функцій.

Автором роботи [4] розглянуто особливості підготовки керівників навчальних закладів у вузах. Розкрита роль компетентнісного підходу в їх підготовці. При цьому основна увага приділена формуванню управлінських функцій керівників.

Отже, управлінські функції керівника будь-якої галузі чи сфери можна реалізувати залежно від його конкретної управлінської діяльності. Відзначається, що одним із основних напрямів підготовки управлінців- 
менеджерів при їх навчанні у вузах $\epsilon$ не тільки використання компетентнісного підходу, але й інтеграція вітчизняної освіти у європейський освітній простір.

Автором роботи [5] обгрунтовано методичний підхід визначення ключових чинників формування управлінської компетентності керівника підприємства. Розкрита роль компетентнісного підходу у формуванні управлінської компетентності керівника підприємства. Дано аналіз публікацій, присвячених вирішенню піднятих питань. Сформульовані та обгрунтовані основні управлінські компетентності керівника підприємства. При цьому основна увага приділена формуванню та аналізу двох груп компетентностей керівника - функціональним і особистісним. При цьому, розкривається сутність управлінської компетентності. Відзначається, що управлінська компетентність керівників, в основному, розглянута в галузі педагогічної науки.

Цілі статті. На основі аналізу літературних джерел і узагальнення результатів власних досліджень сформулювати та обгрунтувати перелік загальних i професійних управлінських компетентностей керівників супермаркетів на прикладі компанії гуртово-роздрібної торгівлі будівельними та господарськими товарами - «Епіцентр К».

Виклад основного матеріалу дослідження 3 повним обгрунтуванням отриманих наукових результатів. Потреба подальшого вдосконалення та переорієнтації організації вітчизняної торгівлі, включаючи керівництво їі підприємствами, обумовлена низкою причин, а саме:

- суттєвими змінами, які відбулися в останні роки у сфері виробництва вітчизняних товарів різного цільового призначення;

- постійне поповнення вітчизняного ринку різноманітними видами імпортних товарів, які суттєво відрізняються своїми властивостями від вітчизняних;

- поява широкої мережі крупноформатних магазинів, універмагів, універсамів, торгових центрів, супермаркетів різних торговельних компаній і фірм, які спеціалізуються на продажі різноманітних груп $\mathrm{i}$ видів непродовольчих товарів вітчизняного та зарубіжного виробництва.

Одним із радикальних аспектів перебудови вітчизняної вищої освіти, включаючи і підготовку фахівців для сфери торгівлі, $є$ широке застосування в навчальному процесі компетентнісного підходу, який в останні десятиріччя 
успішно використовується в європейських країнах. В даній роботі ми обмежимось тільки вивченням можливості використання компетентнісного підходу у вузах сфери торгівлі для підготовки управлінців-менеджерів для керівництва супермаркетами різноманітних торговельних компаній.

Як свідчить аналіз роботи супермаркетів торговельної компанії «Епіцентр К» 3 оптово-роздрібної торгівлі непродовольчими товарами [1,2], їх керівниками в основному працюють випускники товарознавчо-комерційних факультетів вузів сфери торгівлі, які мають відповідний стаж роботи на підприємствах названої компанії.

3 метою підвищення якості та переорієнтації спрямованості змісту управлінської роботи керівників супермаркетів 3 торгівлі непродовольчими товарами представляється доцільним на основі узагальнення літературних джерел і результатів власних досліджень сформулювати та обгрунтувати перелік наступних трьох груп управлінських компетентностей цих керівників: загально торгівельні (табл. 1), товарознавчо-комерційні (табл. 2) і «товарні» (табл. 3).

\section{Таблиця 1}

Перелік загально торговельних компетентностей керівника супермаркету з торгівлі непродовольчими товарами

\begin{tabular}{|c|l|}
\hline $\begin{array}{c}\text { № } \\
3 / \Pi\end{array}$ & \multicolumn{1}{|c|}{ Назва компетентності } \\
\hline 1 & $\begin{array}{l}\text { Знання переліку та специфіки управлінських компетентностей керівника } \\
\text { супермаркету }\end{array}$ \\
\hline 2 & $\begin{array}{l}\text { Знання вимог нормативно-правових документів, що стосується роботи керівника } \\
\text { супермаркету }\end{array}$ \\
\hline 3 & $\begin{array}{l}\text { Здатність використовувати набутих у процесі навчання у вузі товарознавчих, } \\
\text { економічни і правових знань в процесі своєї управлінської діяльності }\end{array}$ \\
\hline 4 & Здатність до виконання конкретних видів управлінської діяльності у супермаркеті \\
\hline 5 & $\begin{array}{l}\text { Вміння виходити із нестандартних ситуацій у своій практичній управлінській } \\
\text { діяльності }\end{array}$ \\
\hline 6 & Вміння керувати трудовим колективом у сфері своєї практичної діяльності \\
\hline 7 & Вміння вирішувати проблемні завдання \\
\hline 8 & $\begin{array}{l}\text { Володіння чуйністю, проникливістю і довірою до співробітників колективу } \\
\text { супермаркету }\end{array}$ \\
\hline 9 & Володіння широтою політичного, економічного та культурного кругозору \\
\hline 10 & $\begin{array}{l}\text { Володіння організаторськими здібностями та вміння толерантно працювати з } \\
\text { колективом супермаркету }\end{array}$ \\
\hline
\end{tabular}


Зупинимось на більш детальній характеристиці названих груп управлінських компетентностей керівників супермаркетів із торгівлі непродовольчими товарами вітчизняної торговельної компанії «Епіцентр К».

Перелік товарознавчо-комерційних компетентностей керівника супермаркету непродовольчими товарами

\begin{tabular}{|c|l|}
\hline $\begin{array}{c}\text { № } \\
3 / \Pi\end{array}$ & \multicolumn{1}{|c|}{ Назва компетентності } \\
\hline 1 & $\begin{array}{l}\text { Вміння керувати організаційно-управлінською діяльністю супермаркету з торгівлі } \\
\text { будівельними та господарськими товарами }\end{array}$ \\
\hline 2 & $\begin{array}{l}\text { 3датність застосовувати товарознавчі знання для організації торговельно-технологічних } \\
\text { процесів у супермаркетах непродовольчих товарів }\end{array}$ \\
\hline 3 & $\begin{array}{l}\text { Вміння аналізувати комерційні пропозиції постачальників конкретних груп і видів } \\
\text { непродовольчих товарів, які реалізуються у супермаркетах }\end{array}$ \\
\hline 4 & $\begin{array}{l}\text { Вміння аналізувати рекламації та пропозиції до якості та асортименту тих груп і видів } \\
\text { непродовольчих товарів, які реалізуються у супермаркеті }\end{array}$ \\
\hline 5 & $\begin{array}{l}\text { Вміння користуватись основними управлінськими характеристиками на всіх етапах } \\
\text { життєвог циклу непродовольчих товарів, з метою оптимізації асортименту тих груп і } \\
\text { видів товарів, які реалізуються супермаркетом }\end{array}$ \\
\hline 6 & $\begin{array}{l}\text { Володіння здатністю систематизації та узагальнення результатів вивчення попиту на } \\
\text { основні види і групи тих непродовольчих товарів, які реалізуються супермаркетами }\end{array}$ \\
\hline 7 & $\begin{array}{l}\text { Знання умов зберігання тих видів і груп непродовольчих товарів, які реалізуються у } \\
\text { супермаркетах }\end{array}$ \\
\hline 8 & $\begin{array}{l}\text { Вміння формувати, аналізувати та регулювати товарні запаси тих видів і груп } \\
\text { непродовольчих товарів, які реалізуються супермаркетом }\end{array}$ \\
\hline 9 & $\begin{array}{l}\text { Знання методів реклами тих видів і груп непродовольчих товарів, які реалізуються } \\
\text { супермаркетами }\end{array}$ \\
\hline сукупності в супермаркетах
\end{tabular}

Цілком зрозуміло, що для набуття випускниками торговельноекономічних вузів наведених в таблицях 1-3 професійних управлінських компетентностей в процесі навчання, вони повинні вивчити ряд профілюючих товарознавчих, комерційних і економічних дисциплін, які безпосередньо чи опосередковано формують їх професійні компетентності, включаючи i управлінські. 
Перелік «товарних» компетентностей керівника супермаркету

будівельних і господарських товарів

\begin{tabular}{|c|c|}
\hline $\begin{array}{l}\text { № } \\
\text { 3/П }\end{array}$ & Назва компетентності \\
\hline 1 & $\begin{array}{l}\text { Знання основних термінів і положень, що стосуються формування асортименту, } \\
\text { оцінки якості, безпечності та маркування будівельних і господарських товарів, які } \\
\text { реалізуються супермаркетами }\end{array}$ \\
\hline 2 & $\begin{array}{l}\text { Знання та вміння користуватись нормативно-правовими документами, в яких } \\
\text { регламентовані вимоги до асортименту, якості та безпечності будівельних і } \\
\text { господарських товарів, що реалізуються супермаркетами }\end{array}$ \\
\hline 3 & $\begin{array}{l}\text { Знання особливостей маркування будівельних і господарських товарів вітчизняного та } \\
\text { зарубіжного виробництва, що реалізуються супермаркетами }\end{array}$ \\
\hline 4 & $\begin{array}{l}\text { Знання особливостей класифікації і вміння характеризувати груповий і видовий } \\
\text { асортимент будівельних і господарських товарів, що реалізуються супермаркетами }\end{array}$ \\
\hline 5 & $\begin{array}{l}\text { Вміння аналізувати структуру групового, видового та внутрішньовидового } \\
\text { асортименту будівельних і господарських товарів, що реалізуються супермаркетами }\end{array}$ \\
\hline 6 & $\begin{array}{l}\text { Знання та вміння оцінити переваги та недоліки аналогічних за призначенням } \\
\text { будівельних та господарських товарів вітчизняного та імпортного виробництва, що } \\
\text { реалізуються супермаркетами }\end{array}$ \\
\hline 7 & $\begin{array}{l}\text { Знання принципів і методів ідентифікації та експертизи окремих видів будівельних і } \\
\text { господарських товарів, що реалізуються супермаркетами }\end{array}$ \\
\hline 8 & $\begin{array}{l}\text { Здатність формулювати напрями оптимізації видового асортименту будівельних і } \\
\text { господарських товарів, що реалізуються супермаркетами }\end{array}$ \\
\hline 9 & $\begin{array}{l}\text { Вміння формувати і управляти структурою групового і видового асортименту } \\
\text { будівельних і господарських і господарських товарів, що реалізуються } \\
\text { супермаркетами }\end{array}$ \\
\hline 10 & $\begin{array}{l}\text { Вміння виявляти причини можливої фальсифікації асортименту, властивостей, } \\
\text { маркування окремих видів і груп будівельних і господарських товарів, що } \\
\text { реалізуються супермаркетами }\end{array}$ \\
\hline
\end{tabular}

Як показав аналіз навчальних планів бакалаврів і магістрів спеціальності 076 Підприємництво, торгівля та біржова діяльність, факультету товарознавства, управління та сфери обслуговування Львівського торговельно-економічного університету на 2017-2022 н.р., набуття необхідних професійних (включаючи управлінські) компетентностей може бути досягнуто в результаті вивчення наступних блоків профілюючих дисциплін бакалаврів (табл.4) і магістрів (табл.5). 
Таблиця 4

Перелік профілюючих дисциплін, які формують професійні компетентності бакалавра спеціальності 076 Підприємництво, торгівля та біржова діяльність

\begin{tabular}{|c|l|c|}
\hline $\begin{array}{c}|c| \\
\text { № } \\
\text { 3/п }\end{array}$ & \multicolumn{1}{|c|}{ Назва дисципліни } & $\begin{array}{c}\text { Кількість } \\
\text { годин }\end{array}$ \\
\hline 1 & Торговельне підприємництво та комерційна діяльність & 88 \\
\hline 2 & Організація торгівлі & 60 \\
\hline 3 & Економіка підприємства & 50 \\
\hline 4 & Бухгалтерський облік & 50 \\
\hline 5 & Торговельна логістика & 50 \\
\hline 6 & Технічне регулювання & 50 \\
\hline 7 & Аналіз господарської діяльності & 50 \\
\hline 8 & Біржова діяльність & 60 \\
\hline 9 & Матеріалознавство та основи технології виробництва товарів & 44 \\
\hline 10 & Менеджмент & 50 \\
\hline 11 & Маркетинг & 60 \\
\hline 12 & Мікробіологія & 50 \\
\hline 13 & Хімія & 60 \\
\hline 14 & Товарознавство плодово-овочевих товарів & 50 \\
\hline 15 & Товарознавство зерно-борошняних і кондитерських виробів & 50 \\
\hline 16 & Товарознавство жирів і молочних товарів & 50 \\
\hline 17 & Товарознавство м’ясних, рибних і яєчних товарів і харчоконцентратів \\
\hline 18 & Товарознавство текстильно-одягових товарів & 60 \\
\hline 19 & Товарознавство взуттєвих і хутряних товарів & 50 \\
\hline 20 & Товарознавство господарських товарів & 60 \\
\hline 21 & Товарознавство культурно-побутових товарів & 50 \\
\hline 22 & Товарознавство пакувальних матеріалів і тари & 60 \\
\hline
\end{tabular}

Таблиця 5

Перелік профілюючих дисциплін, які формують професійні управлінські компетентності магістра спеціальності 076 Підприємництво, торгівля та біржова діяльність

\begin{tabular}{|c|l|c|}
\hline $\begin{array}{c}\text { № } \\
\text { 3/п }\end{array}$ & \multicolumn{1}{|c|}{ Назва дисципліни } & $\begin{array}{c}\text { Кількість } \\
\text { годин }\end{array}$ \\
\hline 1 & Організація та управління інноваційними бізнес-процесами & 72 \\
\hline 2 & Управління якістю & 40 \\
\hline 3 & Товари світового рівня якості & 44 \\
\hline
\end{tabular}

Порівняння наведених $\mathrm{y}$ табл. 1-3 компетентностей керівників супермаркетів непродтоварів і наведеного в табл. 4-5 переліку профілюючих товарознавчо-комерційних дисциплін у навчальних планах бакалаврів i магістрів спеціальності 076 Підприємництво, торгівля та біржова діяльність, факультету товарознавства управління та сфери обслуговування ЛТЕУ 
свідчить про те, що набуття необхідних професійних компетентностей випускниками даного факультету відбувається в основному в процесі їх навчання у бакалавраті. Тому виникає потреба включення в навчальний план магістратури нових профілюючих дисциплін, які б посилювали набуття магістрами більш широкого переліку професійних (особливо управлінських) компетентностей, оскільки саме магістри після закінчення навчання на вказаному факультеті переважно рекомендуються на практичну роботу керівниками різноманітних типів торговельних підприємств з торгівлі різними видами і групами товарів.

Висновки та перспективи подальших досліджень. Представляється доцільним професійні компетентності керівника супермаркету будівельних $\mathrm{i}$ господарських товарів вітчизняної торговельної компанії «Епіцетр К» об’єднати у такі три групи: загальноторговельні, товарознавчо-комерційні та «товарні». При цьому, першочергову увагу слід приділити формуванню та характеристиці «товарних» компетентностей, оскільки їм приділяється ще недостатня увага.

Виявлена потреба посилення професійної управлінської підготовки випускників магістратури, оскільки саме в процесі навчання в магістратурі, випускники факультету товарознавства управління та сфери обслуговування повинні набувати необхідні їм у майбутній професійній діяльності управлінські професійні компетентності керівників торговельних підприємств різного типу.

Існує гостра потреба описання, у сучасних підручниках і з товарознавства та матеріалознавства різних груп непродовольчих товарів, класифікації та характеристики загальних i професійних компетентностей фахівців товарознавчо-комерційного профілю сфери торгівлі.

\section{Список використаних джерел}

1. Герега Г.Ф. Пріоритетні напрями розвитку крупноформатних мережевих структур у сфері торгівлі / Г.Ф. Герега - голова ТОВ «Епіцентр К» // Матеріали Міжнародної науково-практичної конференції «Стратегічні пріоритети розвитку внутрішньої торгівлі України на інноваційних засадах», 2-3 листопада 2017 р.. - м. Львів: Видавництво ЛТЕУ, 2017. - С. 21-23.

2. Клімова А.М. Формування управлінської компетентності майбутніх фахівців 3 товарознавства в системі професійної освіти / Професійна освіта: теоретичні та прикладні аспекти формування компететностей майбутніх фахівців: колективна монографія; частина 
1 / I.I. Доброскок та ін., кер.авт.кол. I.І. Доброскок. - Переяслав-Хмельницький: ФОП Домбровська Я. М., 2016. - 444 с.

3. Максименко С.Д. компетентність як структурна складова самоздійснення особистості: джерела і рушійні сили розвитку / С.Д. Максименко // Компетентнісний підхід в освіті: теоретичні засади і практична реалізація: матеріали методичного семінару 3 квіт. 2014 р., м. Київ. - К.: Ін-т обдарованої дитини НАПН України, 2014. - 370 с.

4. Михайліченко М.В. Компетентнісний підхід до підготовки керівників навчальних закладів / М.В. Михайліченко // Витоки педагогічної майстерності. Збірник наукових праць Полтавського НПУ ім.. В.Г. Короленка. - 2011. - № 8. - С. 3-8.

5. Сєріков Д.О. Визначення напрямків розвитку управлінської компетентності керівників / Д.О. Сєріков // Науковий вісник Ужгородського національного університету, 2017. - В. 14, частина 2. - С. 123-127.

6. Галик I.C. Компетентнісний підхід - основа професійної підготовки товарознавців у вищих навчальних закладах / I.C. Галик, Б.Д. Семак // Вісник Львівського торговельно-економічного університету. Технічні науки. - 2017. - Вип. 18. - С. 16-21.

7. Семак Б.Д. Діагностика та експертиза компетентностей товарознавців текстилю та одягу / Б.Д. Семак, І.С. Галик, Л.Г. Ніколайчук // Матеріали наукової конференції професорсько-викладацького складу та аспірантів Львівського торговельно-економічного університету «Актуальні проблеми економіки і торгівлі в сучасних умовах Свроінтеграції». - Львів: Видавництво ЛТЕУ, 2017. - С. 192-193.

8. Беднарчук М.С. Основні напрямки переорієнтації підготовки товарознавців для потреб легкої промисловості та торгівлі України / М.С. Беднарчук, І.С. Галик, Б.Д. Семак // Збірник праць міжнародної науково-практичної конференції, присвяченої 25-річчю Української технологічної академії (1992-2017) «Технології забезпечення життєдіяльності людини». Київ, 2017. - С. 7-16.

9. Пахолюк О.В. Формулювання професійних компетентностей товарознавців торговельного трикотажного підприємства / О.В. Пахолюк, І.С. Галик, Б.Д. Семак // Актуальні проблеми теорії і практики експертизи товарів // м-ли V міжнародної науковопрактичній інтернет-конференції (м. Полтава, 20-22 березня 2018 р.). - Полтава : ПУЕТ, 2018. - С. 350-353.

Цель. На основе анализа литературных источников и обобщения результатов собственных исследований сформулировать и обосновать перечень общих $и$ профессиональных управленческих компетенций руководителей супермаркетов на примере компании оптово-розничной торговли строчтельными и хозяйственными товарами «Эпицентр К》.

Методика. При проведении исследований использовали предусмотренные действуюшими государственными стандартами методы. Выполнили обзор источников товароведческой и методической литературы, провели мониторинг и систематизацию полученных данных.

Результаты. На основе обобщения литературных источников и результатов собственных исследований сформулирован и обоснован перечень следующих трех групп управленческих компетенций руководителей супермаркетов на примере компании оптово- 
розничной торговли строчтельными и хозяйственными товарами - «Эпицентр К»: общеторговые, товароведческо-коммерческие и «товарные».

Научная новизна. Изучень возможности использования компетентностного подхода в вузах сферы торговли для подготовки управленцев-менеджеров для руководства супермаркетами различных торговых компаний.

Практическая значимость. Обнаружена потребность усиления профессиональной управленческой подготовки выпускников магистратуры, поскольку именно в процессе обучения в магистратуре, выпускники факультета товароведения управления и сферы обслуживания должны приобретать необходимые им в будущей профессиональной деятельности управленческие профессиональные компетентности руководителей торговых предприятий различного типа.

Ключевые слова: компетентность, компетентностный подход, руководитель, управленеи-менеджер, торговая сеть, супермаркет, профессиональные компетентности, непродовольственные товары.

The purpose. Based on the analysis of literary sources and the synthesis of the results of their own research, to formulate and substantiate the list of general and professional managerial competencies of supermarket managers on the example of the wholesale and retail trade in construction and household goods - Epicenter K.

Methodology. In carrying out the research, the methods provided by the current state standards were used. They performed a review of sources of commodity and medical literature, monitored and systematized the data received.

Results. On the basis of the generalization of literary sources and the results of own research, the list of the following three groups of managerial competencies of supermarket managers is formulated and grounded on the example of the wholesale and retail trade in construction and household goods - Epicenter K: commonly traded, commodity-commercial, and commodity

Scientific novelty. The possibility of using the competency approach in the universities of trade sphere for the training of managers-managers for the management of supermarkets of various trading companies has been studied.

Practical significance. The need to strengthen the professional management training of graduates of the magistracy, as it is in the process of studying in the magistracy, graduates of the Faculty of Commodity Management and service sectors must acquire the necessary professional skills in future professional management of managers of various types of trade enterprises.

Key words: competence, competence approach, chairman, manager, trading network, supermarket, professional competence, non-food products.

Стаття рекомендована до публікаиії доктором технічних наук професором Луцького НТУ Байдаковою Л.І. Дата надходження в редакиію 20.01.2019 р. 